\title{
Association of a Genetic Variant in the ALOX5AP with Higher Risk of Ischemic Stroke: A Case-Control, Meta-Analysis and Functional Study
}

\author{
Sophie Domingues-Montanari ${ }^{\mathrm{e}}$ Israel Fernández-Cadenas ${ }^{\mathrm{e}}$ Alberto del Rio-Espinola ${ }^{\mathrm{e}}$

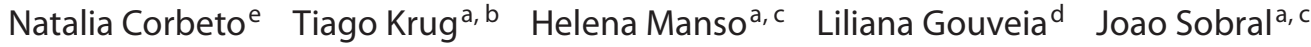 \\ Maite Mendioroz ${ }^{\mathrm{e}}$ Jessica Fernández-Morales ${ }^{\mathrm{e}}$ José Alvarez-Sabin ${ }^{\mathrm{e}}$ Marc Ribó $^{\mathrm{e}}$ \\ Marta Rubiera ${ }^{e}$ Victor Obach ${ }^{f}$ Joan Martí-Fàbregas ${ }^{g}$ Marimar Freijo $^{\text {h }}$ Joaquin Serena ${ }^{i}$ \\ José M. Ferro $^{b, d}$ Astrid M. Vicente ${ }^{a, c}$ Sofia A. Oliveira ${ }^{a, b}$ Joan Montaner ${ }^{e}$ \\ a Instituto Gulbenkian de Ciência, Oeiras, ${ }^{b}$ Instituto de Medicina Molecular, ' Instituto Nacional de Saúde

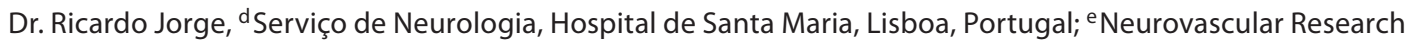 \\ Laboratory and Neurovascular Unit, Neurology and Medicine Departments, Universitat Autònoma de Barcelona, \\ Vall d'Hebron Hospital, ${ }^{\text {f }}$ Stroke Unit, Department of Neurological Sciences, Hospital Clinic and Institut \\ d'Investigacions Biomédiques August Pi i Sunyer, University of Barcelona, and 9 Department of Neurology, Hospital \\ de la Santa Creu i Sant Pau, Barcelona, h'Department of Neurology, Hospital de Basurto, Bilbao, and 'Department of \\ Neurology, Hospital Universitario Dr. Josep Trueta, Institut d'Investigació Biomèdica de Girona, Girona, Spain
}

\section{Key Words}

ALOX5AP · Single nucleotide polymorphism .

Meta-analysis $\cdot$ Stroke $\cdot$ Genetics $\cdot P D E 4 D$

\begin{abstract}
Background: Variants in the 5-lipoxygenase-activating protein (ALOX5AP) and phosphodiesterase 4D (PDE4D) genes have first been associated with ischemic stroke (IS) through whole-genome linkage screens. However, association studies obtained conflicting results. We aimed to investigate the contribution of selected single nucleotide polymorphisms (SNPs) in these genes for the first time in a large lberian population. Methods: A case-control design was used to analyze one SNP in ALOX5AP and five SNPs in PDE4D in a total of 1,092 IS patients and 781 healthy controls of two different subsets from Spain and Portugal. The analysis was adjusted for confounding variables and the results were integrated
\end{abstract}

in a meta-analysis of all case-control studies. In addition, ALOX5AP gene expression levels were determined in controls and IS cases. Results: A first meta-analysis of both subsets showed that the T allele of the SG13S114 SNP in ALOX5AP was a risk factor for IS after Bonferroni correction $[\mathrm{OR}=1.22$ (1.06-1.40); $p=0.006]$. A second meta-analysis of white populations confirmed these results $[O R=1.18(1.07-1.31) ; p=$ 0.001]. ALOX5AP gene expression analysis in a subset of controls and cases revealed that the SG13S114 genotypes modulate mRNA levels of ALOX5AP ( $p=0.001)$ and mRNA levels were higher in IS cases $(2.8 \pm 2.4 \%)$ than in controls $(1.4 \pm$ $1.3 \% ; p=0.003$ ). No association of the variants in PDE4D with IS was observed in our study. Conclusions: The ALOX5AP SG13S114 variant is an independent risk factor for IS in the Iberian population and is associated with ALOX5AP expression levels. The role of this gene in stroke merits further investigation.

Copyright $\odot 2010$ S. Karger AG, Basel

\section{KARGER}

Fax +41613061234 E-Mail karger@karger.ch www.karger.com
(C) 2010 S. Karger AG, Base

$1015-9770 / 10 / 0296-0528 \$ 26.00 / 0$

Accessible online at:

www.karger.com/ced
Joan Montaner

Neurovascular Research Laboratory, Institut de Recerca, Hospital Vall d'Hebron

Pg Vall d'Hebron 119-129

ES-08035 Barcelona (Spain)

Tel. +34 934894 029, Fax +34934894 102, E-Mail 31862jmv@ comb.cat 


\section{Introduction}

Environmental and genetic factors contribute to the development of complex diseases such as ischemic stroke (IS), the leading cause of disability and third cause of death in developed countries $[1,2]$. The DeCode study highlighted the implication of single nucleotide polymorphisms (SNPs) and haplotypes in the 5-lipoxygenase-activating protein (ALOX5AP or FLAP) and phosphodiesterase $4 \mathrm{D}$ (PDE4D) genes in IS in the Icelandic population through genome-wide linkage scan [3-5]. The study showed that a haplotype in the ALOX5AP gene, HapA defined by the SNPs SG13S25, SG13S114, SG13S89 and SG13S32, conferred an increased risk of suffering myocardial infarction and stroke $[5,6]$. Moreover, several SNPs in the PDE4D gene (SNP41, SNP45, SNP56, SNP87 and SNP89) were strongly associated with the combined cardioembolic and atherothrombotic stroke subtypes. A risk haplotype was also described, composed of SNP45 and microsatellite AC008818-1, which conferred a risk about 1.8 times higher of suffering stroke to the $16 \%$ of the general population that carries at least one copy [4].

However, replication of these results in other populations has proven difficult. Concerning the ALOX5AP gene, 4 studies in European populations confirmed later the association with stroke [6-9], whereas 4 studies and a meta-analysis did not [10-14]. Concerning the PDE4D gene, 14 studies have been published as follow-up in European populations, 11 of which claimed replication of the findings [10-13, 15-21] and 3 did not $[7,22,23]$. Staton et al. [17], in 2006, observed a significant association with IS of SNP41, SNP83 and SNP87 through meta-analysis. On the contrary, in a more recent and complete meta-analysis on 5,200 and 6,600 stroke patients and controls, respectively, it was shown that none of the genetic variants studied was robustly and reproducibly associated with stroke, when the data from the original report was excluded [24]. Interestingly, Nilsson-Ardnor et al. [16], in 2005, published a study on a candidate region linkage approach for stroke in families from Sweden and replicated the linkage of the $P D E 4 D$ region on chromosome $5 \mathrm{q}$.

This study aimed to investigate the contribution of genetic variants in the ALOX5AP and PDE4D to IS through a three-step approach: a large case-control analysis in the never tested before Iberian population, a meta-analysis of all case-control studies available for white ethnicity including our results, and functional studies of selected genetic variants.

\section{Material and Methods}

\section{Study Population}

We used a case-control design on two datasets, from Spain and Portugal. Spanish IS cases were unrelated consecutive patients who were admitted to the Emergency Department of University Hospitals throughout Spain, recruited within the first $3 \mathrm{~h}$ after symptom onset. Only patients with a nonlacunar IS involving the vascular territory of the basilar or middle cerebral arteries were included. Occlusion was assessed by transcranial Doppler ultrasonography [25]. Control participants were healthy volunteers older than 65 years with no neurovascular and cardiovascular history, as well as family history of stroke, ascertained by direct interview before recruitment. Portuguese IS cases were unrelated patients, who were under the age of 65 at stroke onset and were recruited throughout Portugal. Stroke was defined by the presence of a new focal neurological deficit, with an acute onset and symptoms and signs persisting for more than $24 \mathrm{~h}$, and confirmed by computed tomography scan and/or magnetic resonance imaging [26]. Control participants were healthy volunteers free of stroke as ascertained by direct interview before recruitment. In both subsets, patients with a clinically known inflammatory or malignant disease were excluded from the study. Details on socioeconomic and demographic characteristics were obtained from all subjects by questionnaires, together with information on smoking, dyslipidemia, hypertension, diabetes mellitus and current medication use. A pooling-data analysis was performed, based on the minimal available data for each study. Smoking was defined as ever smoking by interview. Hypertension was defined as systolic blood pressure $\geq 140 \mathrm{~mm} \mathrm{Hg}$ and diastolic blood pressure $\geq 85 \mathrm{~mm} \mathrm{Hg}$, self-reported history and/ or treatment for hypertension. Diabetes mellitus was defined by self-reported history and/or any treatment for diabetes type 2 . Dyslipidemia was defined as increased lipid concentrations (cholesterol $>200 \mathrm{mg} / \mathrm{dl}$ or triglycerides $>200 \mathrm{mg} / \mathrm{dl}$ ), self-reported history and/or any treatment for dyslipidemia. Informed written consent was obtained from all subjects and the local Ethics Committee approved the study. All subjects were of European white ancestry.

\section{Genetic Analysis}

One SNP in the ALOX5AP gene (SG13S114) and five SNPs in the PDE4D gene (SNP41, SNP45, SNP56, SNP87, SNP89) were investigated. These polymorphisms were genotyped using the SNPlex $^{\mathrm{TM}}$ (Applied Biosystems, Inc., Foster City, USA), Sequenom ${ }^{\circledR}$ iPLEX, or TaqMan ${ }^{\circledR}$ (Applied Biosystems) technologies.

\section{Statistical Methods}

Sample size for adequate power was calculated using the Ene 2.0 software. Deviation from the Hardy-Weinberg equilibrium (HWE) was assessed using a $\chi^{2}$-test with 1 degree of freedom. A $\chi^{2}$ or Fisher's exact test, as appropriate, was used to compare categorical variables between groups. Continuous variables were compared between groups with the Student's $\mathrm{t}$ test. Bonferroni correction was used to adjust for multiple comparison testing. The odd ratios (ORs) and 95\% confidence intervals (CIs) for the effect on IS risk were estimated by logistic regression analysis adjusted for the effects of classical stroke risk factors. SPSS ${ }^{\odot} 15.0$ was used for all statistical analyses. 
Table 1. Baseline characteristics of IS cases and controls

\begin{tabular}{|c|c|c|c|c|c|c|c|c|c|}
\hline & \multicolumn{3}{|l|}{ Spain } & \multicolumn{3}{|l|}{ Portugal } & \multicolumn{3}{|l|}{ Overall } \\
\hline & $\begin{array}{l}\text { controls } \\
(n=263)\end{array}$ & $\begin{array}{l}\text { IS cases } \\
(\mathrm{n}=527)\end{array}$ & $\mathrm{p}$ value & $\begin{array}{l}\text { controls } \\
(\mathrm{n}=518)\end{array}$ & $\begin{array}{l}\text { IS cases } \\
(\mathrm{n}=565)\end{array}$ & $\mathrm{p}$ value & $\begin{array}{l}\text { controls } \\
(\mathrm{n}=781)\end{array}$ & $\begin{array}{l}\text { IS cases } \\
(\mathrm{n}=1,092)\end{array}$ & $\mathrm{p}$ value \\
\hline Age, years & $72.1 \pm 6.9$ & $70.6 \pm 11.9$ & 0.072 & $63.0 \pm 6.8$ & $52.4 \pm 9.3$ & $<0.001^{*}$ & $66.0 \pm 8.1$ & $61.2 \pm 14.0$ & $<0.001^{*}$ \\
\hline Men, n (\%) & $121(45.7)$ & $287(54.5)$ & $0.019^{*}$ & $238(45.9)$ & $361(63.9)$ & $<0.001^{*}$ & $359(45.8)$ & $648(59.3)$ & $<0.001^{*}$ \\
\hline Smokers, n (\%) & $42(15.8)$ & $130(25.9)$ & $0.001^{*}$ & $146(28.7)$ & $272(48.9)$ & $<0.001^{*}$ & $188(24.3)$ & $402(38.0)$ & $<0.001^{*}$ \\
\hline Hypertension, n (\%) & $119(44.7)$ & $308(59.2)$ & $<0.001^{*}$ & $192(37.7)$ & $289(57.2)$ & $<0.001^{*}$ & $311(40.1)$ & $597(58.2)$ & $<0.001^{*}$ \\
\hline Diabetes mellitus, n (\%) & $19(7.1)$ & $121(23.1)$ & $<0.001^{*}$ & $58(11.7)$ & $95(17.7)$ & $0.007^{*}$ & $77(10.1)$ & $216(20.4)$ & $<0.001^{*}$ \\
\hline Dyslipidemia, n (\%) & $81(30.5)$ & $173(33.1)$ & 0.445 & $325(63.0)$ & $328(62.4)$ & 0.834 & $406(51.9)$ & $501(47.8)$ & 0.082 \\
\hline
\end{tabular}

Data are mean \pm SD or number (\%). Statistically significant $\mathrm{p}$ values are marked with an asterisk.

\section{Meta-Analysis}

Systematic review of the literature was performed in order to calculate the association of several SNPs with IS through metaanalysis. Studies published up to December 31st, 2008 on the association between ALOX5AP genetic variants and the risk of IS were identified in the MEDLINE database through the following terms: ALOX5AP, FLAP, lipoxygenase, polymorphism, gene, stroke, cerebral infarction, mutation, genotype, cerebrovascular disease, allele. Articles were included in the meta-analysis if the language was English, French or Spanish, and if the population studied was of White ethnicity. Data for analysis were extracted independently from each study by two investigators. The SNPs included in the meta-analysis were genotyped in at least 2 independent studies and if data were available for our own dataset, it was also included. Between studies heterogeneity was estimated with the $\mathrm{I}^{2}$ of Higgins and Thompson, and $\mathrm{I}^{2}>0.50$ or $\mathrm{p}$ value $<0.05$ were considered indicators of inconsistency between studies. Nonetheless, test for association was calculated in all cases with a random effects model from DerSimonian and Laird. The statistical tools used for the analysis were downloaded from the Critical Appraisal Skills Program at www.redcaspe.org. ORs were used to compare distributions of alleles and genotypes between cases and controls.

\section{Gene Expression Analysis}

RNA was extracted from all available samples, 19 healthy controls and 22 IS cases, in which blood was obtained at baseline (less than $3 \mathrm{~h}$ after onset of stroke symptoms) in the Vall d'Hebron Hospital. Two EDTA tubes were centrifuged at 3,500 rpm for $15 \mathrm{~min}$ to obtain the white blood cell fraction, which was immediately preserved in RNAlater ${ }^{\circledR}\left(\right.$ Ambion $^{\circledR}$, Foster City, USA) at $-80^{\circ} \mathrm{C}$, and total RNA was isolated by RiboPure-Blood ${ }^{\mathrm{TM}}$ Kit (Ambion). cDNA synthesis was performed using High-Capacity cDNA Archive Kit (Applied Biosystems, Inc., Foster City, Calif., USA). mRNA levels were determined by quantitative Real Time PCR, using a standard TaqMan PCR kit protocol and TaqMan fluorogenic probes with a 7500 Real Time PCR System (Applied Biosystems). The probes were located in the ALOX5AP (Hs00233463_ml) and the Cyclophilin A (PPIA) genes (Hs99999904_m1); the latter ran as housekeeping gene to normalize the results. All reactions were run in triplicate on three 96-well plates, using a unique sample as endogenous calibrator control in each one, and analyzed using the
Applied Biosystems SDS 7500 system software. The results are expressed in percent depending on a healthy calibrator sample used in the experiments.

\section{Results}

\section{Case-Control Study}

Sample size was calculated to obtain a power of 0.80 with a significance level of 0.05 using the data from the two original Icelandic studies $[4,5]$. The mean risk allele frequency of the 6 SNPs (SG13S114 of ALOX5AP and SNP41, SNP45, SNP56, SNP87, SNP89 of PDE4D) was calculated in cases (77.7\%) and in controls (68.4\%). Based on this average $10 \%$ difference in risk allele frequency between cases and controls, we calculated the sample size necessary for each subset, considering that we had approximately the same number of cases and controls available in the Portuguese dataset, and approximately half the number of controls than cases in the Spanish subset. The minimal sample size necessary was then 216 controls and 504 cases in the Spanish subset and 309 cases and 309 controls in the Portuguese subset, with an expected theoretical effect size OR of 1.67 (1.16-2.39). Finally, 263 controls and 527 cases from Spain and 518 controls and 565 cases from Portugal were included in the analyses. Established risk factors, including male gender, diabetes mellitus, hypertension and cigarette smoking were observed at a higher frequency in the IS group. On the other hand, dyslipidemic status did not differ between cases and controls (table 1).

One SNP in ALOX5AP and five SNPs in PDE4D were examined for association with IS. Genotype frequencies differed significantly from those predicted by the HWE in the control group for SNP45 of PDE4D in the Portuguese study (table 2). Considering an additive model, be- 
Table 2. Association results of PDE4D and ALOX5AP with IS in the Spanish and Portuguese subsets

\begin{tabular}{|c|c|c|c|c|c|c|c|c|c|c|}
\hline Gene & dbSNP ID & ID & Allele & $\begin{array}{l}\text { HWE in } \\
\text { controls } \\
\text { p value }\end{array}$ & $\begin{array}{l}\text { Frequency } \\
\text { controls } \\
\%\end{array}$ & $\begin{array}{l}\text { Frequency } \\
\text { cases } \\
\%\end{array}$ & $\begin{array}{l}\text { Crude OR } \\
(95 \% \mathrm{CI})\end{array}$ & $\begin{array}{l}\text { Crude } \\
\text { p value }\end{array}$ & $\begin{array}{l}\text { Adjusted OR } \\
(95 \% \mathrm{CI})^{1}\end{array}$ & $\begin{array}{l}\text { Adjusted } \\
\text { p value }^{1}\end{array}$ \\
\hline \multicolumn{11}{|l|}{ Spain } \\
\hline PDE4D & rs1396476 & SNP89 & $\mathrm{T}$ & 0.214 & 17.1 & 13.3 & $0.74(0.56-0.99)$ & $0.043^{*}$ & $0.70(0.51-0.96)$ & $0.026^{*}$ \\
\hline PDE4D & rs2910829 & SNP87 & $\mathrm{C}$ & 0.118 & 44.4 & 48.1 & $1.16(0.94-1.43)$ & 0.167 & $1.19(0.95-1.50)$ & 0.124 \\
\hline PDE4D & rs702553 & SNP56 & $\mathrm{T}$ & 0.923 & 31.9 & 31.1 & $1.03(0.82-1.30)$ & 0.768 & $1.06(0.83-1.35)$ & 0.652 \\
\hline PDE4D & rs152312 & SNP41 & $\mathrm{T}$ & 0.408 & 14.4 & 9.9 & $1.54(0.72-3.27)$ & 0.262 & $2.44(0.94-6.31)$ & 0.067 \\
\hline PDE4D & rs12188950 & SNP45 & $\mathrm{T}$ & 0.998 & 14.1 & 14.2 & $0.99(0.72-1.34)$ & 0.932 & $0.92(0.66-1.27)$ & 0.600 \\
\hline ALOX5AP & rs10507391 & SG13S114 & $\mathrm{T}$ & 0.118 & 58.6 & 63.4 & $1.22(0.98-1.53)$ & 0.070 & $1.15(0.91-1.45)$ & 0.249 \\
\hline \multicolumn{11}{|l|}{ Portugal } \\
\hline PDE4D & rs1396476 & SNP89 & $\mathrm{T}$ & 0.787 & 13.4 & 14.8 & $1.13(0.88-1.45)$ & 0.339 & $1.09(0.76-1.54)$ & 0.647 \\
\hline PDE4D & rs2910829 & SNP87 & $\mathrm{C}$ & 0.228 & 45.8 & 47.5 & $1.07(0.90-1.28)$ & 0.443 & $1.10(0.86-1.41)$ & 0.435 \\
\hline PDE4D & rs702553 & SNP56 & $\mathrm{T}$ & 0.941 & 32.1 & 35 & $0.87(0.72-1.06)$ & 0.163 & $0.96(0.74-1.25)$ & 0.770 \\
\hline PDE4D & rs152312 & SNP41 & $\mathrm{T}$ & 0.726 & 11.3 & 14.1 & $0.77(0.51-1.17)$ & 0.221 & $0.72(0.42-1.21)$ & 0.214 \\
\hline PDE4D & rs12188950 & SNP45 & $\mathrm{T}$ & $0.0001^{*}$ & 12.5 & 15.2 & $0.80(0.62-1.03)$ & 0.081 & $0.68(0.48-0.97)$ & $0.036^{*}$ \\
\hline ALOX5AP & rs10507391 & SG13S114 & $\mathrm{T}$ & 0.120 & 58.2 & 62.8 & $1.21(1.01-1.46)$ & $0.037^{*}$ & $1.30(1.01-1.68)$ & $0.041^{*}$ \\
\hline \multicolumn{11}{|l|}{ Overall } \\
\hline PDE4D & rs1396476 & SNP89 & $\mathrm{T}$ & 0.709 & 14.6 & 14.1 & $0.95(0.79-1.15)$ & 0.621 & $0.91(0.74-1.12)$ & 0.391 \\
\hline PDE4D & rs2910829 & SNP87 & $\mathrm{C}$ & $0.006^{*}$ & 45.3 & 47.8 & $1.10(0.97-1.26)$ & 0.143 & $1.15(0.99-1.34)$ & 0.062 \\
\hline PDE4D & rs702553 & SNP56 & $\mathrm{T}$ & 0.600 & 32.0 & 33.1 & $0.95(0.82-1.10)$ & 0.506 & $0.98(0.84-1.15)$ & 0.844 \\
\hline PDE4D & rs152312 & SNP41 & $\mathrm{T}$ & 0.826 & 12.0 & 13.4 & $0.89(0.62-1.27)$ & 0.514 & $0.99(0.65-1.52)$ & 0.976 \\
\hline PDE4D & rs12188950 & SNP45 & $\mathrm{T}$ & $<0.001^{*}$ & 13.0 & 14.7 & $0.87(0.71-1.05)$ & 0.154 & $0.84(0.67-1.04)$ & 0.106 \\
\hline ALOX5AP & rs10507391 & SG13S114 & $\mathrm{T}$ & 0.514 & 58.3 & 63.1 & $1.22(1.06-1.40)$ & $0.004^{*}$ & $1.22(1.04-1.42)$ & $0.013^{*}$ \\
\hline
\end{tabular}

Statistically significant $\mathrm{p}$ values are marked with an asterisk. dbSNP ID = Identification number in the dbSNP database.

${ }^{1}$ Logistic regression adjusted for sex, age, diabetes, smoking and hypertension.

Table 3. Meta-analysis results of the six SNPs in PDE4D and ALOX5AP with IS in the Spanish and Portuguese subsets

\begin{tabular}{|c|c|c|c|c|c|c|c|c|c|c|}
\hline Gene & SNP ID & Allele & $\begin{array}{l}\text { Number } \\
\text { of case } \\
\text { alleles }\end{array}$ & $\begin{array}{l}\text { Number } \\
\text { of control } \\
\text { alleles }\end{array}$ & $\begin{array}{l}\text { Frequency } \\
\text { cases } \\
\%\end{array}$ & $\begin{array}{l}\text { Frequency } \\
\text { controls } \\
\%\end{array}$ & $\begin{array}{l}\text { Hetero- } \\
\text { geneity } \\
\mathrm{I}^{2}\end{array}$ & $\begin{array}{l}\text { Hetero- } \\
\text { geneity } \\
\text { p value }\end{array}$ & $\begin{array}{l}\text { Per allele } \\
\text { OR }(95 \% \text { CI })\end{array}$ & $\mathrm{p}$ value \\
\hline PDE4D & rs1396476 & $\mathrm{T}$ & 2,034 & 1,550 & 14.06 & 14.65 & 0.75 & $0.031^{*}$ & $0.92(0.61-1.39)$ & 0.698 \\
\hline PDE4D & rs2910829 & $\mathrm{C}$ & 2,002 & 1,514 & 47.80 & 45.31 & 0.00 & 0.566 & $1.11(0.97-1.27)$ & 0.140 \\
\hline PDE4D & rs702553 & $\mathrm{T}$ & 1,930 & 1,510 & 66.94 & 68.01 & 0.19 & 0.257 & $0.94(0.80-1.11)$ & 0.449 \\
\hline PDE4D & rs152312 & $\mathrm{T}$ & 1,056 & 374 & 13.35 & 12.03 & 0.59 & 0.117 & $0.99(0.51-1.91)$ & 0.974 \\
\hline PDE4D & rs12188950 & $\mathrm{T}$ & 1,998 & 1,490 & 14.71 & 13.02 & 0.08 & 0.296 & $1.15(0.94-1.41)$ & 0.186 \\
\hline ALOX5AP & rs10507391 & $\mathrm{T}$ & 1,898 & 1,490 & 63.12 & 58.32 & 0.00 & 0.950 & $1.22(1.06-1.40)$ & $0.006^{*}$ \\
\hline
\end{tabular}

Statistically significant $\mathrm{p}$ values are marked with an asterisk. Columns 8 and 9: inconsistency between studies.

fore and after adjusting for the confounding variables age, gender, diabetes mellitus, cigarette smoking and hypertension, the T allele of the SNP89 in PDE4D was a risk factor for IS in the Spanish subset, but this association could not be replicated in the Portuguese sample. However, in the Portuguese subset, the T allele of the SG13S114 $\mathrm{SNP}$ in $A L O X 5 A P$ was a risk factor for IS (OR $=1.21,95 \%$
CI: $1.01-1.46, \mathrm{p}=0.037)$ and this association remained significant after adjusting for the different confounding variables $(\mathrm{OR}=1.30,95 \% \mathrm{CI}: 1.01-1.68, \mathrm{p}=0.041)$. There was also a tendency for association in the Spanish subset $(\mathrm{OR}=1.22,95 \% \mathrm{CI}: 0.98-1.53, \mathrm{p}=0.070)$. Overall, the pooling-data analysis revealed that the $\mathrm{T}$ allele of the SG13S114 was a risk factor for IS before (OR $=1.22,95 \%$ 
Fig. 1. Flow diagram of the study selection process for the ALOX5AP meta-analysis.

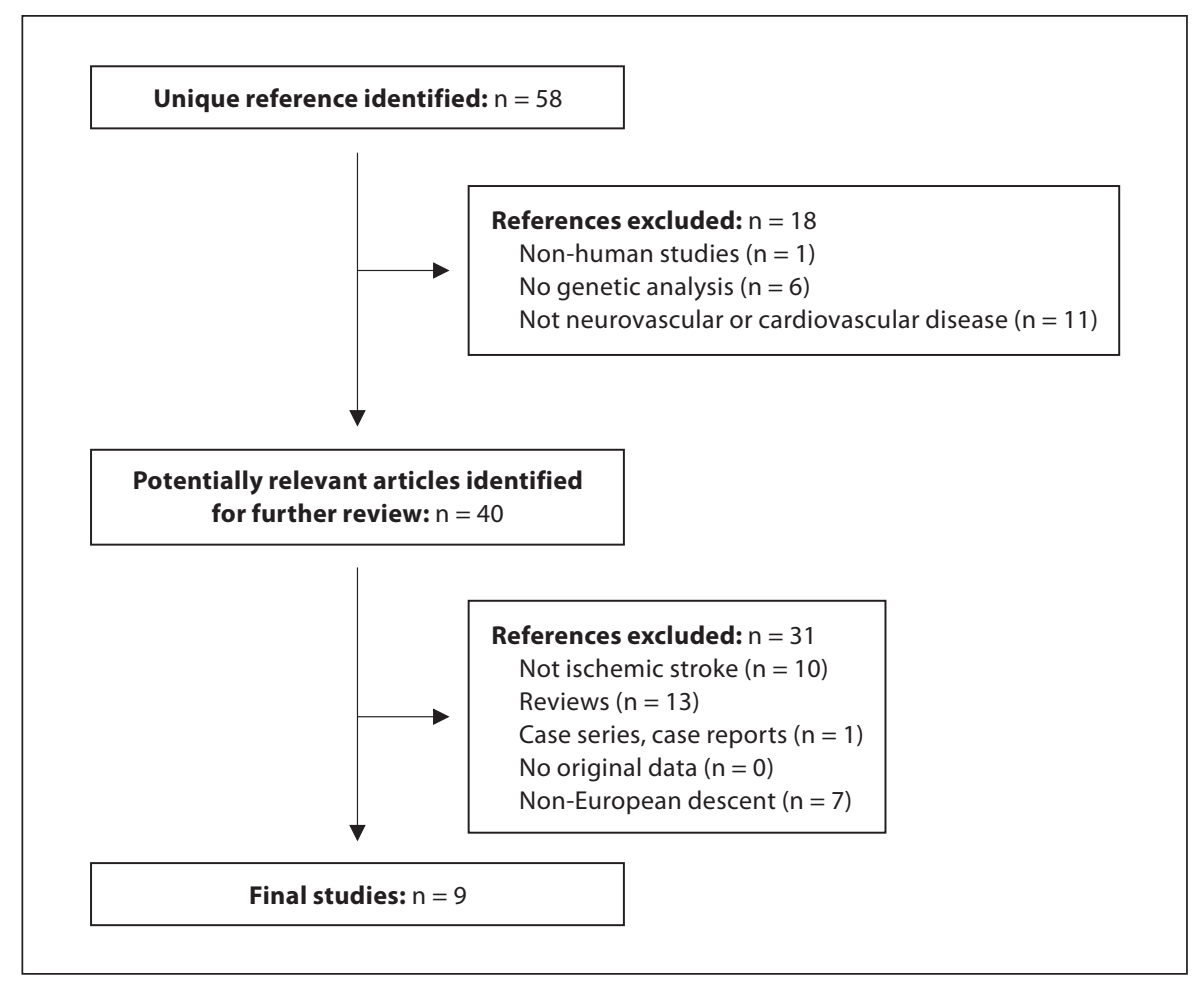

CI: $1.06-1.40, \mathrm{p}=0.004)$ and after logistic regression for classical stroke risk factors $(\mathrm{OR}=1.22,95 \% \mathrm{CI}: 1.04-1.42$, $\mathrm{p}=0.013)$.

We next performed a meta-analysis of both Spanish and Portuguese studies (table 3), which indicated that overall the T allele of the SG13S114 SNP in ALOX5AP was indeed a risk factor for IS and this association survived the Bonferroni correction for multiple testing $(\mathrm{OR}=1.22$, 95\% CI: 1.06-1.40, $\mathrm{p}=0.006$ ). The heterogeneity between the two subsets for this SNP was low $\left(\mathrm{I}^{2}=0.00, \mathrm{p}=0.950\right)$. None of the SNPs studied in the PDE4D gene was associated with IS in the meta-analysis.

\section{Meta-Analysis}

A flow diagram of the study selection process for the meta-analysis of the ALOX5AP gene is presented in figure 1 . We performed a meta-analysis on studies carried out in White samples, including our data and 9 studies on ALOX5AP (table 4). The analysis included data on two haplotypes and five out of twelve SNPs studied in cited papers for which data was available from at least two independent studies (table 5). The highest number of subjects was obtained from five different studies for the SG13S114 SNP, with 3,318 case alleles and 2,923 control alleles. The meta-analysis results indicate that this SNP is associated with IS (OR $=1.18,95 \%$ CI: 1.07-1.31, $\mathrm{p}=$ 0.001), in concordance with the results obtained in our population (fig. 2). Moreover, the heterogeneity between studies was low $(\mathrm{p}=0.896)$.

\section{Gene Expression Analysis}

Expression of the ALOX5AP gene was determined in 19 controls and 22 IS cases (fig. 3). A significant difference in the mean relative levels of RNA expression could be observed between controls and cases $(\mathrm{p}=0.003)$, IS cases showing higher levels $(280 \pm 240 \%)$ than controls (140 $\pm 130 \%)$. Moreover, in the control group, RNA levels depend on the genotype of the SG13S114SNP ( $p=0.001$ ), AA carriers $(260 \pm 100 \% ; n=5)$ presenting higher levels than AT carriers $(110 \pm 120 \% ; n=8)$, which in turn presented higher levels than TT carriers $(80 \pm 90 \% ; \mathrm{n}=6)$. However, no association between ALOX5AP RNA levels and SG13S114 genotype could be observed in the group of IS cases $(\mathrm{p}=0.866)$. Levels of expression did not differ between controls $(260 \pm 100 \% ; n=5)$ and cases $(310 \pm$ $310 \% ; \mathrm{n}=7)$ carrying the AA genotype $(\mathrm{p}=0.660)$. But we did observe an increase in the relative levels of $\mathrm{T}$ allele carriers between controls $(100 \pm 110 \% ; \mathrm{n}=14)$ and IS cases $(260 \pm 210 \% ; \mathrm{n}=15)(\mathrm{p}<0.001)$. 
Table 4. Case-control studies on the association of ALOX5AP with IS in White populations

\begin{tabular}{lllllr}
\hline PubMed ID & Country & Year & First author & Journal & $\begin{array}{c}\text { Total number } \\
\text { of subjects }\end{array}$ \\
\hline 14770184 & Iceland & 2004 & Helgadottir & Nature Genetics & 1,326 \\
15640973 & Scotland & 2005 & Helgadottir & American Journal of Human Genetics & 1,160 \\
15731479 & Germany & 2005 & Lohmussaar & Stroke & Annals of Neurology \\
16130105 & USA & 2005 & Meschia & Stroke & 640 \\
16778124 & USA & 2006 & Zee & Human Genetics & 818 \\
17387518 & USA & 2007 & Kaushal & Journal of Neurological Sciences & 1,436 \\
17655870 & Sweden & 2007 & Kostulas & European Journal of Human Genetics & 1,321 \\
18398440 & Sweden & 2008 & Lövkvist & Stroke & 1,805 \\
18323512 & UK & 2008 & Bevan & &
\end{tabular}

Table 5. Meta-analysis of the association of $A L O X 5 A P$ variants with IS in White populations

\begin{tabular}{|c|c|c|c|c|c|c|c|c|c|}
\hline SNP ID & $\begin{array}{l}\text { Number } \\
\text { of studies }\end{array}$ & $\begin{array}{l}\text { Number } \\
\text { of case } \\
\text { alleles }\end{array}$ & $\begin{array}{l}\text { Number } \\
\text { of control } \\
\text { alleles }\end{array}$ & $\begin{array}{l}\text { RAF } \\
\text { cases }\end{array}$ & $\begin{array}{l}\text { RAF } \\
\text { controls }\end{array}$ & $\begin{array}{l}\text { Hetero- } \\
\text { geneity } \\
\mathrm{I}^{2}\end{array}$ & $\begin{array}{l}\text { Hetero- } \\
\text { geneity } \\
\text { p value }\end{array}$ & $\begin{array}{l}\text { Per allele } \\
\text { OR }(95 \% \text { CI })\end{array}$ & $\mathrm{p}$ value \\
\hline SG13S25 & 4 & 2,100 & 1,588 & 10.3 & 9.5 & 0.00 & 0.783 & $1.12(0.89-1.40)$ & 0.337 \\
\hline SG13S32 & 3 & 1,154 & 1,227 & 51.5 & 50.3 & 0.00 & 0.648 & $1.05(0.89-1.23)$ & 0.551 \\
\hline SG13S89 & 5 & 2,294 & 2,372 & 7.0 & 4.5 & 0.63 & $0.028^{*}$ & $1.54(0.99-2.39)$ & 0.055 \\
\hline SG13S106 & 2 & 511 & 491 & 68.7 & 66.8 & 0.67 & 0.082 & $1.10(0.69-1.74)$ & 0.694 \\
\hline SG13S114 & 5 & 3,318 & 2,923 & 65.2 & 61.6 & 0.00 & 0.896 & $1.18(1.07-1.31)$ & $0.001^{*}$ \\
\hline HapA & 4 & 2,018 & 2,302 & 15.4 & 13.4 & 0.64 & $0.040^{*}$ & $1.18(0.88-1.58)$ & 0.266 \\
\hline НарВ & 3 & 1,341 & 1,593 & 7.1 & 6.5 & 0.00 & 0.692 & $1.08(0.81-1.44)$ & 0.623 \\
\hline
\end{tabular}

Statistically significant $\mathrm{p}$ values are marked with an asterisk. RAF $=$ Risk allele frequency. Columns 7 and 8 : inconsistency between studies.

\section{Discussion}

The design of the present study constitutes a threestep approach. First of all, we selected some of the most interesting SNPs that were associated with stroke in the DeCode study in an Icelandic population. These SNPs were examined through case-control analysis in a large Iberian sample, a population that has never been tested before for association with the ALOX5AP and PDE4D genes. The data obtained were then included in a new and complete meta-analysis of white ancestry case-control studies with additional markers and haplotypes. Finally, functional studies were performed through gene expression analysis. We identified the SG13S114 SNP of the ALOX5AP gene as an independent risk factor for stroke, both in the case-control study in our population and in the meta-analysis of White ethnicity populations and show that this polymorphism regulates $A L O X 5 A P$ RNA levels.

The T allele of the SG13S114 variant is part of the HapA haplotype markers that was described as a risk factor for IS in the original study. The only study that analyzed the effect of the SG13S114 SNP in a European population observed identical results, which are that the $\mathrm{T}$ allele of this polymorphism is associated with a higher risk of IS [7]. Kaushal et al. [8], in an American White population, also replicated the association of ALOX5AP with IS, but not of the SG13S114 SNP. However, the frequency of this SNP in their population was quite different, indicating that the White American and the White European population frequencies are not comparable. This could explain the fact that two other studies in American White populations did not observe an association of the SG13S114 SNP with IS [10, 11]. Other studies 


\begin{tabular}{|c|c|c|c|c|}
\hline \multicolumn{2}{|l|}{ Study } & OR $(95 \% \mathrm{Cl})$ & $p$ value & Weight \% \\
\hline Kaushal et al. [8] & -1 & $1.17(0.80-1.72)$ & 0.405 & 6.2 \\
\hline Zee et al. [11] & $\rightarrow$ & $1.00(0.70-1.43)$ & 1.000 & 7.0 \\
\hline Lõhmussaar et al. [7] & 1 & $1.18(1.00-1.38)$ & $0.046^{*}$ & 35.0 \\
\hline Meschia et al. [10] & $\rightarrow$ & $1.16(0.78-1.72)$ & 0.459 & 5.7 \\
\hline Domingues-Montanari et al. [2] & 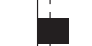 & $1.22(1.06-1.41)$ & $0.004^{*}$ & 46.1 \\
\hline Overall $(95 \% \mathrm{Cl})$ & $\phi$ & $1.18(1.07-1.31)$ & $<0.001^{*}$ & \\
\hline$\Gamma$ & & 7 & & \\
\hline 0.10 & 1.00 & $\begin{array}{c}10.00 \\
\text { OR }\end{array}$ & & \\
\hline
\end{tabular}

Fig. 2. Forest plot for carriers of the T allele of the SG13S114 SNP in the ALOX5AP gene. * Statistically significant $\mathrm{p}$ value.

published a replication of the association of ALOX5AP with IS, but did not study or publish the results obtained for this particular SG13S114 SNP [6, 9]. Also, two studies investigated either other variants in the gene or the HapA directly $[12,13]$. Considering other ethnicities, two studies in Chinese populations also support a role for the ALOX5AP gene in IS [27, 28].

To definitively elucidate the contribution of the SG13S114 variant on the risk of stroke in white populations, we performed a new meta-analysis, including all data available in the literature and our own results. Metaanalyses are statistical tools that permit to combine the results of several studies that address the same hypothesis. It is widely considered that resulting overall averages are more powerful estimates of the true effect size than those derived from a single study under a given single set of assumptions and conditions, if study characteristics are well controlled. Our meta-analysis on the ALOX5AP gene confirmed that the SG13S114 SNP is associated with IS, in concordance with the results obtained in our population.

The putative function of the SG13S114 variant is unknown since it is located in an intronic region, but we demonstrate here that RNA levels depend on the genotypes of this SNP in our control group. No study has explored the possible function of the ALOX5AP gene before on stroke. Therefore we decided to investigate the expression levels of this gene in more than 40 samples and showed that T allele carriers of the SG13S114 SNP present lower levels of ALOX5AP gene expression, which might indicate that low RNA levels of $A L O X 5 A P$ is a risk factor for IS. This gene encodes the 5-lipoxygenase activating protein (FLAP), a protein for which the only known role is the involvement in the initial step of leukotriene biosynthesis, a process that can be completely inhibited by

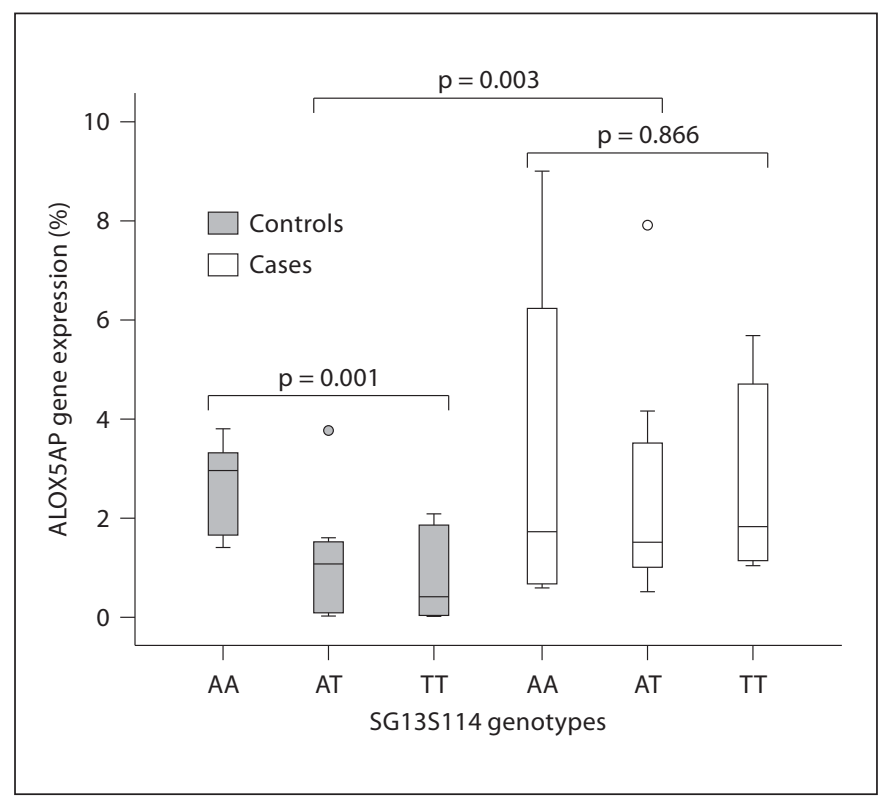

Fig. 3. Box plot of the expression of the ALOX5AP gene in controls and IS cases according to their SG13S114 genotype. RNA levels are expressed in median percentage compared to a housekeeping marker.

compounds that bind FLAP. More specifically, membrane-embedded FLAP, which has no known enzymatic activity, selectively transfers arachidonic acid to 5-lipoxygenase and enhances sequential oxygenation of arachidonic acid to 5(S)-hydroperoxyeicosatetraenoic acid and dehydration to leukotriene $A_{4}$ [29]. Leukotriene $A_{4}$ can then be converted either to pro-inflammatory leukotriene $\mathrm{B}_{4}$ or to the bronchoconstrictive, vasoconstrictive and pro-inflammatory cysteinyl leukotrienes. Those pro- 
inflammatory effects of FLAP and the production of reactive molecules such as superoxide anions [6] have been linked to respiratory diseases, allergic diseases and cardiovascular diseases. The ALOX5AP gene has also been linked to the risk of stroke, restenosis, myocardial infarction and atherosclerosis. It was shown that male carriers of the HapA at-risk haplotype had significantly greater production of leukotriene $\mathrm{B}_{4}$ in neutrophils [5].

In our study, we observed higher ALOX5AP gene expression levels in IS cases than in controls, although in the cases, RNA levels did not depend on the genotype of the SG13S114 SNP. This might indicate that during the acute phase of an IS, ALOX5AP levels are increased, probably as part of the inflammation process. This is supported by the fact that $\mathrm{T}$ carriers in cases present statistically higher levels of ALOX5AP RNA than T carriers in controls. The lack of association with the genotype in the IS cases could be due to a general increase in RNA levels, masking the effect of the polymorphism. However, our analysis presents several limitations, such as the small sample size, the difficulty to access brain infarcted tissue and the widespread alteration of mRNA levels across different gene and gene sets in diseased individuals, which limit the relevance of these results. We do not have results of ALOX5AP RNA levels in other time points than the acute phase but considering the results in the control group, we assume that the $\mathrm{T}$ allele is associated with low RNA levels. We hypothesize that these low RNA levels might be a risk factor for IS, for example by altering the inflammatory response, thus playing a role in neuro- and cardiovascular diseases. However, more studies are needed to demonstrate this hypothesis.

Concerning the PDE4D gene, we found no association of the five SNPs analyzed in the PDE4D gene with the risk of IS in our population, although some SNPs did not respect the HWE and thus question the veracity of those results. Bevan et al. [9], similarly to our findings, showed that no genetic variant presented a strong and consistent association to IS, suggesting that the associations observed in Iceland for the PDE4D gene might be restricted only to specific populations. We also performed a new and complete meta-analysis of white ancestry case-control studies of the PDE4D gene in IS, but we did not observe any association (data not shown). However, a recent study on the differential expression of genes upon acute IS in human peripheral blood mononuclear cells showed that expression profiles were the most significantly different between IS patients and healthy subjects for the PDE4D gene out of around 10,000 probe sets [30].
Most studies published as a follow-up to the original article present limitations in the number of variants tested, small size of samples analyzed and the subtyping of the different etiologies of stroke [31,32]. In our case, technical difficulties prevented the analysis of more variants, including the other SNPs constituting the HapA haplotype of the ALOX5AP gene, as well as the AC008818-1 microsatellite in the PDE4D gene, which were associated with stroke in the initial paper. Moreover, subtype analysis of the patients would have been very interesting since phenotypic differences among IS patients is mainly related to different stroke etiologies; unfortunately TOAST information was not available for all cases, limiting subtyping to a small number of subjects. Population stratification might also be a source of replication failure. On the other hand, the overall sample size used was considered sufficient to observe a variation of at least 0.06 in the minor allele frequency of any SNP between cases and controls with a significance level of 0.05 and a power of 0.80 . Also, the interaction with other traditional risk factors was well controlled. Considering the results of the metaanalysis, publication bias is an important potential confounding factor. However, heterogeneity between studies was well assessed statistically with random effects analysis.

\section{Summary}

In conclusion, the present study is the first to investigate the role of the PDE4D and ALOX5AP genes on the risk of developing IS in an Iberian population, indicating that the T allele of the SG13S114 genetic variant in the ALOX5AP gene is an independent risk factor for IS and is associated with ALOX5AP expression levels. Moreover, we present here the results of a new large meta-analysis on the ALOX5AP gene in IS, comprising 3,318 case alleles and 2,923 control alleles, showing that the SG13S114 SNP is a risk factor for IS in White populations. The role of this gene in stroke merits further investigation.

\section{Acknowledgments}

We are deeply grateful to all study participants, neurologists and nurses of the Stroke and Laboratory Units from the Vall d'Hebron Hospital and of the Portuguese Stroke Genetics (PORTSGEN) Group, and to M. Quintana, D. Giralt, A. Penalba and S. García-Menéndez. We would also like to thank the CEGEN and the Instituto Gulbenkian de Ciência’s Genomics Unit. 
This study was funded by a grant from the Spanish government (Geno-tPA project FIS PJ060586), the stroke research network (RENEVAS) and the Ramón Areces Foundation. S.D.-M. is the recipient of a grant from the Ramón Areces Foundation, I.F.-C. a postdoctoral grant from the Vall d'Hebron Research Institute (IRVH), A.d.R.-E. received a grant from the Vall d'Hebron Research Institute (IRVH), M.M. received a grant for Formation in Investigation (FI05/00081), and J.F.-M. was a re- cipient of a grant from La Marató (Chromig Exp. 072310). This work was also supported in part by the Portuguese Fundação para a Ciência e a Tecnologia (FCT) grant PTDC/SAU-GMG/ 64426/2006, FCT fellowships (TK, HM), and the Fundação AstraZeneca/Faculdade de Medicina de Lisboa research fellowship (LG). The Neurovascular Research Laboratory takes part in the International Stroke Genetics Consortium ISGC and in the RENEVAS network.

\section{References}

1 Feigin VL: Stroke epidemiology in the developing world. Lancet 2005;365:2160-2161.

-2 Domingues-Montanari S, Mendioroz M, del Rio-Espinola A, Fernández-Cadenas I, Montaner J: Genetics of stroke: a review of recent advances. Expert Rev Mol Diagn 2008;8: 495-513.

-3 Gretarsdottir S, Sveinbjörnsdottir S, Jonsson $\mathrm{HH}$, Jakobsson F, Einarsdottir E, Agnarsson U, Shkolny D, Einarsson G, Gudjonsdottir $\mathrm{HM}$, Valdimarsson EM, Einarsson OB, Thorgeirsson G, Hadzic R, Jonsdottir S, Reynisdottir ST, Bjarnadottir SM, Gudmundsdottir T, Gudlaugsdottir GJ, Gill R, Lindpaintner K, Sainz J, Hannesson HH, Sigurdsson GT, Frigge ML, Kong A, Gudnason V, Stefansson K, Gulcher JR: Localization of a susceptibility gene for common forms of stroke to $5 \mathrm{q} 12$. Am J Hum Genet 2002;70:593-603.

-4 Gretarsdottir S, Thorleifsson G, Reynisdottir ST, Manolescu A, Jonsdottir S, Jonsdottir T, Gudmundsdottir T, Bjarnadottir SM, Einarsson $\mathrm{OB}$, Gudjonsdottir HM, Hawkins $\mathrm{M}$, Gudmundsson G, Gudmundsdottir H, Andrason H, Gudmundsdottir AS, Sigurdardottir M, Chou TT, Nahmias J, Goss S, Sveinbjörnsdottir S, Valdimarsson EM, Jakobsson F, Agnarsson U, Gudnason V, Thorgeirsson G, Fingerle J, Gurney M, Gudbjartsson D, Frigge ML, Kong A, Stefansson K, Gulcher JR: The gene encoding phosphodiesterase $4 \mathrm{D}$ confers risk of ischemic stroke. Nat Genet 2003;35:131-138.

-5 Helgadottir A, Manolescu A, Thorleifsson G, Gretarsdottir S, Jonsdottir H, Thorsteinsdottir U, Samani NJ, Gudmundsson G, Grant SF, Thorgeirsson G, Sveinbjornsdottir S, Valdimarsson EM, Matthiasson SE, Johannsson $\mathrm{H}$, Gudmundsdottir O, Gurney ME, Sainz J, Thorhallsdottir M, Andresdottir M, Frigge ML, Topol EJ, Kong A, Gudnason V, Hakonarson H, Gulcher JR, Stefansson $\mathrm{K}$ : The gene encoding 5-lipoxygenase activating protein confers risk of myocardial infarction and stroke. Nat Genet 2004;36: 233-239.

- 6 Helgadottir A, Gretarsdottir S, St Clair D, Manolescu A, Cheung J, Thorleifsson G, Pasdar A, Grant SF, Whalley LJ, Hakonarson H, Thorsteinsdottir U, Kong A, Gulcher J, Ste- fansson K, MacLeod MJ: Association between the gene encoding 5-lipoxygenase-activating protein and stroke replicated in a Scottish population. Am J Hum Genet 2005; 76:505-509.

-7 Lõhmussaar E, Gschwendtner A, Mueller JC, Org T, Wichmann E, Hamann G, Meitinger T, Dichgans M: ALOX5AP gene and the PDE4D gene in a central European population of stroke patients. Stroke 2005;36:731-736.

-8 Kaushal R, Pal P, Alwell K, Haverbusch M, Flaherty M, Moomaw C, Sekar P, Kissela B, Kleindorfer D, Chakraborty R, Broderick J, Deka R, Woo D: Association of ALOX5AP with ischemic stroke: a population-based case-control study. Hum Genet 2007;121: 601-607.

-9 Bevan S, Dichgans M, Wiechmann HE, Gschwendtner A, Meitinger T, Markus HS: Genetic variations in members of the leukotriene biosynthesis pathway confer an increased risk of ischemic stroke: a replication study in two independent populations. Stroke 2008;39:1109-1114.

10 Meschia JF, Brott TG, Brown RD Jr, Crook R, Worrall BB, Kissela B, Brown WM, Rich SS, Case LD, Evans EW, Hague S, Singleton A, Hardy J; SWISS Study Group; ISGS Study Group; MSGD Study Group: Phosphodiesterase $4 \mathrm{D}$ and 5-lipoxygenase activating protein in ischemic stroke. Ann Neurol 2005;58: 351-361.

11 Zee RY, Cheng S, Hegener HH, Erlich HA, Ridker PM: Genetic variants of arachidonate 5-lipoxygenase-activating protein, and risk of incident myocardial infarction and ischemic stroke: a nested case-control approach. Stroke 2006;37:2007-2011.

12 Kostulas K, Gretarsdottir S, Kostulas V, Manolescu A, Helgadottir A, Thorleifsson G, Gudmundsson LJ, Thorsteinsdottir U, Gulcher JR, Stefansson K, Hillert J: PDE4D and ALOX5AP genetic variants and risk for ischemic cerebrovascular disease in Sweden. J Neurol Sci 2007;263:113-117.

13 Lövkvist H, Smith JG, Luthman H, Höglund P, Norrving B, Kristoffersson U, Jönsson AC, Lindgren AG: Ischaemic stroke in hypertensive patients is associated with variations in the PDE4D genome region. Eur J Hum Genet $2008 ; 16: 1117-1125$.
14 Zintzaras E, Rodopoulou P, Sakellaridis N: Variants of the arachidonate 5-lipoxygenase-activating protein (ALOX5AP) gene and risk of stroke: a HuGE gene-disease association review and meta-analysis. Am J Epidemiol 2009; 169:523-532.

15 van Rijn MJ, Slooter AJ, Schut AF, Isaacs A, Aulchenko YS, Snijders PJ, Kappelle LJ, van Swieten JC, Oostra BA, van Duijn CM: Familial aggregation, the PDE4D gene, and ischemic stroke in a genetically isolated population. Neurology 2005;65:1203-1209.

16 Nilsson-Ardnor S, Wiklund PG, Lindgren P, Nilsson AK, Janunger T, Escher SA, Hallbeck B, Stegmayr B, Asplund K, Holmberg D: Linkage of ischemic stroke to the PDE4D region on $5 \mathrm{q}$ in a Swedish population. Stroke 2005;36:1666-1671.

17 Staton JM, Sayer MS, Hankey GJ, Attia J, Thakkinstian A, Yi Q, Cole VJ, Baker R, Eikelboom JW: Association between phosphodiesterase $4 \mathrm{D}$ gene and ischaemic stroke. J Neurol Neurosurg Psychiatry 2006;77: 1067-1069.

18 Woo D, Kaushal R, Kissela B, Sekar P, Wolujewicz M, Pal P, Alwell K, Haverbusch M, Ewing I, Miller R, Kleindorfer D, Flaherty M, Chakraborty R, Deka R, Broderick J: Association of phosphodiesterase 4D with ischemic stroke: a population-based case-control study. Stroke 2006;37:371-376.

19 Brophy VH, Ro SK, Rhees BK, Lui LY, Lee JM, Umblas N, Bentley LG, Li J, Cheng S, Browner WS, Erlich HA: Association of phosphodiesterase $4 \mathrm{D}$ polymorphisms with ischemic stroke in a US population stratified by hypertension status. Stroke 2006;37: 1385-1390.

20 Song Q, Cole JW, O'Connell JR, Stine OC, Gallagher M, Giles WH, Mitchell BD, Wozniak MA, Stern BJ, Sorkin JD, McArdle PF, Naj AC, Xu Q, Gibbons GH, Kittner SJ: Phosphodiesterase $4 \mathrm{D}$ polymorphisms and the risk of cerebral infarction in a biracial population: the Stroke Prevention in Young Women Study. Hum Mol Genet 2006;15:2468-2478.

21 Fidani L, Clarimon J, Goulas A, Hatzitolios AI, Evans W, Tsirogianni E, Hardy J, Kotsis A: Association of phosphodiesterase 4D gene G0 haplotype and ischaemic stroke in a Greek population. Eur J Neurol 2007;14:745-749. 
\22 Kuhlenbäumer G, Berger K, Huge A, Lange E, Kessler C, John U, Funke H, Nabavi DG, Stögbauer F, Ringelstein EB, Stoll M: Evaluation of single nucleotide polymorphisms in the phosphodiesterase $4 \mathrm{D}$ gene (PDE4D) and their association with ischaemic stroke in a large German cohort. J Neurol Neurosurg Psychiatry 2006;77:521-524.

23 Nilsson-Ardnor S, Janunger T, Wiklund PG, Lackovic K, Nilsson AK, Lindgren P, Escher SA, Stegmayr B, Asplund K, Holmberg D: Genome-wide linkage scan of common stroke in families from northern Sweden. Stroke 2007;38:34-40.

24 Bevan S, Dichgans M, Gschwendtner A, Kuhlenbäumer G, Ringelstein EB, Markus HS: Variation in the PDE4D gene and ischemic stroke risk: a systematic review and meta-analysis on 5,200 cases and 6,600 controls. Stroke 2008;39:1966-1971.
25 Montaner J, Fernandez-Cadenas I, Molina CA, Ribó M, Huertas R, Rosell A, Penalba A, Ortega L, Chacón P, Alvarez-Sabín J: Poststroke C-reactive protein is a powerful prognostic tool among candidates for thrombolysis. Stroke 2006;37:1205-1210.

26 Rosa A, Fonseca BV, Krug T, Manso H, Gouveia L, Albergaria I, Gaspar G, Correia M, Viana-Baptista M, Simões RM, Pinto AN, Taipa R, Ferreira C, Fontes JR, Silva MR, Gabriel JP, Matos I, Lopes G, Ferro JM, Vicente AM, Oliveira SA: Mitochondrial haplogroup $\mathrm{H} 1$ is protective for ischemic stroke in Portuguese patients. BMC Med Genet 2008;9: 57.

27 Shen CD, Zhang WL, Sun K, Wang YB, Zhen YS, Hui RT: Interaction of genetic risk factors confers higher risk for thrombotic stroke in male Chinese: a multicenter casecontrol study. Ann Hum Genet 2007;71:620629.

28 Zhang WL, Yang XM, Shi J, Sun K, Hui RT: Polymorphism of SG13S114T/A in the ALOX5AP gene and the risk for stroke in a large Chinese cohort. Yi Chuan Xue Bao 2006;33:678-684
29 Evans JF, Ferguson AD, Mosley RT, Hutchinson JH: What's all the FLAP about? 5-lipoxygenase-activating protein inhibitors for inflammatory diseases. Trends Pharmacol Sci 2008;29:72-78.

30 Grond-Ginsbach C, Hummel M, Wiest T, Horstmann S, Pfleger K, Hergenhahn M, Hollstein M, Mansmann U, Grau AJ, Wagner $S$ : Gene expression in human peripheral blood mononuclear cells upon acute ischemic stroke. J Neurol 2008;255:723-731.

31 Pruissen DM, Kappelle LJ, Rosendaal FR, Algra A: Genetic association studies in ischaemic stroke: replication failure and prospects. Cerebrovasc Dis 2009;27:290-294.

32 Fatar M, Stroick M, Steffens M, Senn E, Reuter B, Bukow S, Griebe M, Alonso A, Lichtner $\mathrm{P}$, Bugert $\mathrm{P}$, Meitinger T, Wienker TF, Hennerici MG: Single-nucleotide polymorphisms of MMP-2 gene in stroke subtypes. Cerebrovasc Dis 2008;26:113-119. 